\title{
Abode in heaven
}

Paul and life after death in 2 Corinthians 5:1-10

\section{Pieter Verster ${ }^{1}$}

\begin{abstract}
In 2 Corinthians 5:1-10, Paul uses different methods to explain his view on life after death. He uses the metaphors of a tent, a building, clothing and being at home with God. It is clear that Paul accepted that the future with God is certain and that he will receive a building from God in heaven even though he may die. There is life with God even before the final resurrection. A life of bliss is assured for those who believe in God. This has implications for missions, namely that the future with God is ascertained.

Keywords: Metaphors, Future with God, Tent, Building from God, Paul's theology, Intermediate state, Missiological implications
\end{abstract}

\section{Introduction}

The belief in life after death is a dominant theme in the New Testament, with many passages referring to it (refer to Matthew 7:21-23, 10:28, 11:22-24, 16:24-28, 19:28-30, 22:23-33, and especially 25:31-46, Mark 8:34-38, 13:13, 3:26, Luke 10:13-15, 12:33-34, 16:19-29, John 3:10-21, 5:24-29, 6:37-40, 11:23-25, 14:1-4, 1 Corinthians 15 and 2 Corinthians 5). The New Testament gives some indication about life after death but in many instances it is still shrouded in mystery (refer to the texts above). According to these texts, Paul and the evangelists deemed life after death as something they attest to. They are of the opinion that it can be experienced in many ways. Before God who revealed Himself as the God of life they experienced life as real and not imaginary. God created the reality and they experienced life before Him. Jesus's parables refer to life after death (refer to Luke 12:35-48, 13:22-30, 16:19-29). In these parables and in his reference to the last days and the second coming of the Son of God, he refers to aspects thereof. Concerning the parables, it is made clear that there is life after death and that there is a distinction between people in the afterlife. The well-known parable of Lazarus (Luke 16:1931) explains how Lazarus, as a poor man, had died and was taken into the bosom of Abraham where he enjoyed a feast and glory, while the rich man had to suffer, because he did not honour God and his neighbour. It is also mentioned that there

Pieter Verster is Professor of Missiology at the University of Free State. He can be contacted at versterp@ufs.ac.za 
will be a last judgement. According to this last judgement, some people will enter into glory while others will suffer (Matthew 25:31-46).

Paul, although not always in the same way, often refers to life after death. In the first and second letters to Corinthians he explains that the resurrection of Christ makes life with Him possible, even after death. In this regard 1 Corinthians 15 is of importance because the aspect of the resurrection is explained clearly. He explains that it is difficult to understand, but that it is like a grain that falls into the ground and later sprouts into quite a new existence. Death has been conquered and the resurrection of the body is a wonderful reality in the promise of God. Two Corinthians also refers to aspects of life after death. Paul's personal expectations are expanded by his explanation of his view on eternity. Two Corinthians 5:1-10 is a notoriously difficult passage/pericope, but also highly informative regarding the Christian belief of life after death and eschatology.

\section{Background of 2 Corinthians}

\subsection{Corinthians as letter}

Collins (2013:3-5) explains that the letters to the Corinthians are generally regarded as authentic Pauline letters (see also Harris 2005:1ff). Paul visited Corinth during his second missionary voyage somewhere around AD 50 (Acts 18:1-18). The letters, however, do not offer definite confirmation on the aspects referred to in Acts. It is well known that at least four letters were written. The first letter, then 1 Corinthians, a third letter, also known as the tearful or severe letter, followed by 2 Corinthians. The text of 2 Corinthians is well attested and parts are found on papyri as early as $\mathrm{AD} 200$ (P 46). It is a long letter by ancient standards. It is a highly personal letter: "Paul, in fact reveals so much of himself in this letter that it can aptly be called the most personal of his letters" (Collins 2013:5). Some new issues are the reasons for the letter, such as to spare them another painful visit, to demonstrate his affection for the Corinthians, to put their obedience to his apostolicity to test and to make them aware of him as their spiritual father (Harris 2005:4). It is addressed to all the saints in Achaia, which means that a larger audience than just the Corinthians would read the letter (Omanson \& Ellington 1993:11).

Paul dictated his letters to a scribe. He was an orator and evangelist. He used many rhetorical devices in his letter. Paul is in debate with his adversaries and readers and very often departs from prescribed letter-writing aspects, such as explained by Demetrius (Collins 2013:6). An abrupt transition in the way in which the letter is structured is sometimes regarded as unacceptable (Collins 2013:6-7).

The troublesome intruders in 2 Corinthians are regarded as Judaizers, although not the same as those in Galatians (Collins 2013:13). Harris regards them as protognostic in their views of denial of future bodily resurrection and their pride in 
knowledge or gnosis after he discussed the possibility that they are Jewish Christian Gnostics. They were Judaizers from Palestine who infiltrated the church (Harris 2005:85). They proclaimed their assurance with power and might; Paul with humbleness and brokenness (Matera 2003:24). In 2 Corinthians 5:1-10 Paul is aware of his own fragility, weakness and difficulties, but he does not succumbed to these, because he believes in the future life (Collins 2013:15). His mortality and the future which awaits him are described in many metaphors.

In 2 Corinthians 5:1-10 the implications of life after death are explained. There are many views on this pericope and some (Barrett 1976:150ff, Harris 2005:365ff, Dunn 1998:487.ff.) regard it as a clear and visible statement of the fact that we will receive life after death, namely that our earthly life is like a tent broken down and destroyed, but that we will have life after death in the fullness of a building from God. Others (Pop 1971:138ff.), are of the opinion that it is all about the second coming of Christ and that not so much must be read into the explanation of the tent being pulled down, and the way in which the tent is pulled down, but that we must understand the second coming of Christ as bringing a whole new life with Him to us (see Pop 1971:138 to 141).

\subsection{The macro context of 2 Corinthians 5:1-10}

Paul's authentic letters deal with essential aspects of the Christian faith, reconciliation with God and salvation. It also deals with aspects of eschatology, death and life after death. Dunn (1998:26) is of the opinion that various engagements with Paul's theology is possible and that dialogue with the Apostle is necessary. Especially relevant is the fact that Paul has in mind the scheme of already and not yet (Dunn 1998:466). Something decisive has already happened but the work of God is not yet completed. The future holds the resurrection of the body as consummation of God's promises (Dunn 1998:488). In Christ the future is possible (Dunn 1998:493). Schnelle (2005:596) explains how Paul expects God trough his life-giving power to continue his relation with a person even after death. The Jesus Christ history continues even after death. God's love overcomes death (2005:597). The resurrection of the body is the culmination of this truth. (2005:596). Wright (2005:137) regards the Messianic renewal in Christ as essential for the understanding of Paul's eschatology: "We can the trace, in Paul's exposition of what God did in Jesus the Messiah, all the key elements of the Jewish eschatology, now reshaped around Jesus" (2005:142-143). According to Wright (2005:143) this obviously includes resurrection and the Messiaship and its immediate consequences, namely the arrival of God's kingdom. Future life in the body is possible in Christ. In Christ God makes life after death in the resurrection new. (2005:142-143).

Wright NT (2008:153) explains that Paul regards the resurrection of the dead as not debatable. The future is secured in the resurrection of the dead. This is also the 
true aspect of life after death. The longing must therefore be not to go to heaven one day but to be resurrected in the new transformed body. Although he accepts that the dead in Christ are included in his salvation in what he accepts as an intermediate state, he regards the future as God's full and comprehensive renewal of the cosmos in the resurrection (Wright NT 2008:172)

Harris (2005:365ff.) explains that 2 Corinthians 5:1-10 is clearly related to 2 Corinthians $4: 7-18$ because it states that in the midst of affliction, perplexity and persecution, the hope of divine intervention is present; a hope of life after death. Paul is confident in the presence of death (Harris 2005:366). By walking in the realm of faith, Paul experiences the future possibility of new life in Christ (Harris 2005:366). In 2 Corinthians 4:7-18 Paul explains that the life of Christ is present even in the mortal flesh and that that the relation with God is possible even in this life because Jesus makes life with God possible,, but he then explains that it also has implications for the future life (Barrett 1976:143).

\section{Themes in 2 Corinthians 5:1-10}

3.1 Semiotic implications of the metaphors

Paul uses metaphors abundantly such as those concerning the church in 1 Corinthians 12. The semiotic implications of these metaphors must be acknowledged. They affect the referred aspects, explain the suggested issue, and are interrelated. The criteria for identifying the metaphors are where Paul relates a certain issue to an image to explain it better. The metaphors relate to the issues at hand and Paul uses it to enhance the understanding thereof. Van der Watt (2000:6) gives full attention to the definition and nature of metaphors. He explains that some form of comparison is necessary but that two disparate meanings are linked. It is when some kind of identification and comparison is made possible and meaning is transferred: "To a certain extent the interpretation process is brought to a halt and thrown into 'reverse"'. The reader is referred back to the semantic competence of the word to look for alternative possibilities of performance (2000:8).

Barrett (1976:150ff.) refers to quite a few important aspects. Turning to the text itself it is clear that Paul firstly refers to the fact that the tent in which he lives will be broken down and destroyed, but he explains that even if the tent is broken down and destroyed there will be a building from God, an eternal house in heaven not built by human hands. Barrett (1976:150) is of the opinion that Paul failed to understand the dualism of his adversaries, but that he explains the glory of his eschatology. In fact, Barrett (1976:150) is of the opinion that in both epistles Paul's real concern focuses on the way Christians are to live here and now. On the other hand, he also makes it very clear that the future life is a reality and that there will be a future in the abode in heaven, a house from heaven 
that will be put on like new clothes. Paul uses different metaphors and images to explain his idea. First of all, the tent and then the abode in heaven, the eternal house in heaven made by God. He also uses the metaphor of clothes to explain that the subjects need to be clothed so that they will not be found naked. Barrett (1976:150) is of the opinion that it should not be regarded as a reference to the proximity of the feast of tabernacles.

One of the main questions is whether Paul uses the metaphors in 2 Corinthians 5:1-10 as evidence of the resurrected body (Wright NT 2008:153) or the heavenly state of believers until the Parousia (Barrett 1976:151ff).

Referring to the metaphors, it is suggested that 2 Corinthians 5:1-10 explains the wonder of immediate life after death with Christ in heaven as an intermediate state until the Parousia.

\subsubsection{Tent}

The tent is insecure and impermanent. Barrett (1976:151) refers to the fact that it is a common picture of the earthly life (see also Wisdom 9:15). Bultmann (1985:131) refers extensively to the use of tent, or dwelling, or house, for our earthly existence in antiquity, frequently found in Hellenistic literature (see also Isaiah 38:12). The implication is that Paul makes use of a well-known metaphor in which the tent is usually regarded as the temporary abode of the soul. Barrett (1976:151) is also of the opinion that Paul wants to release the soul, or whatever the non-material part of man should be called, from all corporal containment. Thus, the tent is taken down in transformation at the end of the parousia of Christ when the person will be clothed, as stated by Paul, by the building from heaven. In the tent we groan; the tent is a place of affliction, but we long to put on the new building of God-our habitation which comes from heaven (Barrett 1976:152).

Paul refers to the time the tent is pulled down as the moment of death, according to Omanson and Ellington (1993:89). They also state that the present suffering leading to the dismantling of the tent is relevant in this regard.

Dunn (1998:489) explains the implications of this metaphor: "But its most obvious function is to express Paul's confidence (4.16) that the present process of wasting away ('outer nature') and renewal ('inner nature) will climax in the transformation into the resurrection body (4.17-5.4), of which the Spirit is already the first instalment and guarantee (5.5)."

\subsubsection{Building}

Paul explains his hope, especially in 2 Corinthians 5:5,6. He hopes that by putting on this new building from heaven, he will not be discovered to be naked. Harris (2005:375ff.) refers to different possibilities, namely a) present possession of the 
spiritual body in 1 . heaven, or 2 . on earth in embryonic form, or b) future acquisition of the spiritual body, 1. at death, a) in reality, or b) as an ideal possession actualised at the parousia, or 2 . at the parousia.

Harris is of the opinion that it only refers to those who will one day experience the parousia (Harris 2005:383). Wolff (1989:103-104) is of the opinion that the building from God is not the individual resurrected body. He refers to many viewpoints, such as that it is the new aeon in heaven, the higher existence, the church, or the eschatological church. He views it as the impersonal life in heaven.

The relation to the Hellenistic view on nakedness is very important, because it is generally not regarded as unbecoming but Barrett (1976:154) refers to the fact that some people see the soul as being naked and undesirable, while Philo (De Virtutibus 76) shares the Greek view of the nakedness of the soul as a desirable thing. Paul's view, however, was that nakedness has to be shunned. Paul does not hold a positive view of the nakedness of the soul. For him, nakedness was something to abhor and avoid (2 Corinthians 5:3). Is the nakedness of the bodily existence $\sin$ ? Is it the natural body? Is it body without Christ? Is it his understanding of the Corinthianostic position? Barrett (1976:154ff) states that 2 Corinthians5:4 shows that we are burdened in the tent, because we groan. We groan for the fullness of the spirit, so that the spirit can fill us in order to experience the fullness of the spirit, instead of groaning in fear of death. Barrett (1976:156) explains that Paul is not in the ordinary sense afraid of death; he dreads death precisely for the reason he proceeds to give-because he would be much happier to survive until the parousia. He continues to explain this idea that means not to die, but to be transformed immediately ( 1 Corinthians $15: 51$ ) by the substitution of the spiritual for the natural body (1 Corinthians 15:44); to put on the new dwelling over the old in the notion of the heavenly clothing and the heavenly body and Paul's horror of nakedness. Paul wishes for the mortal to be swallowed up by the glory of God-and this can be done through the Spirit. The Spirit gives this fullness of the exchange so that he can experience it on the basis of faith and therefore he is confident that God will give this fullness of life (See Dunn 1998:494) Schnelle (2005:486) writes: "Pauline theology is profoundly stamped with the insight that since Jesus Christ has been raised from the dead, the Spirit of God is again at work." (see 2 Cor 1:22;5:5 Rom 8:23). Wright (2005:145) is of the opinion that Paul's eschatology is reimagined around the Spirit.

Collins (2013:105) refers to the fact that Paul uses the metaphor of the building to emphasise that God alone produces the resurrected body. This house is, therefore, not made by hands, but a spiritual home made by God (Omanson \& Ellington 1993:90). 


\subsubsection{Clothing}

Pop (1971:138) explains that the metaphor of the tent is not about the end of life in our death, but rather the parousia, and that the tent will be exchanged for the heavenly abode at the parousia. When the parousia takes place, there will be a different new life. One will be clothed from above and will be changed so that the new life can be possible. This will happen at the end of life when the parousia takes place. Paul longs (2 Corinthians 5:6) for the time that he will no longer be in the tent, but in the glory of living in heaven (2 Corinthians 5:8) after Christ has come to take all the troubles of this life away and he can enjoy the fullness of the glory of God. This longing of Paul is also very present in Philippians 1:23. The metaphor of the clothing by the heavenly body, as seen by the Apostle, is not only to cover the earthly body, but to absorb and transfigure it (Hughes 1962:168). Paul longs for the heavenly garment to experience the fullness of being clothed and not being naked. He polemicizes against the Gnostics (Bultmann 1985:138). Barnett (1988:99) understands the clothing as the moment Paul became a Christian and he was clothed in Christ and had the hope of eternal life; God supplies the new life.

\subsubsection{At home with God}

The fourth metaphor according to Barnett (1988:100) implies living by faith and not sight. Walking in faith is essential for the person awaiting heaven. Life in the spirit is living in the expectation of the realisation of the future.

\section{Main implications}

\subsection{Paul's theology}

Dunn (1998:487ff) explains that Paul's theology would be incomplete if it did not state that life is not a repeating cycle of birth and rebirth. The process of salvation would be incomplete if did not include the final vindication of the resurrection of the body. If the believer hoped only for this life on God he/she would be pitiable (1 Cor. 15:19). The obvious element of the hope in God is the resurrection of the body. Dunn (1998:488) writes: "The importance of that hope lay not the least in the fact that so many aspects of Paul's theology come together in it. It is the immediate consequence of cross and resurrection (1 Corinthians 15), is integral to the gospel $(15,12-19)$, and confirms that victory over death is central to the gospel (15.21$22,26,54-57)$. It resolves forever the tension between flesh and body (15.42-54) It completes God's purpose in creating humanity by renewing the image of God in resurrected humanity (15.45-49) it is the final outworking of the process of inner renewal and outward decay (2 Cor. 4.16-5.5)." This all was made possible by Christ's resurrection. Christ's resurrected body is the one the new resurrected bodies will conform to. Christ is the firstborn and the prototype. Dunn has full 
confidence that Paul expects life after death. In 1 Corinthians the emphasis is on the resurrected body. In 2 Corinthians 5:1-10 the emphasis is on the fact that life after death is explained by bringing down the tent and being found endowed by the building in heaven. In both instances Paul explains life after death.

Schreiner (2001:37) also emphasises that Paul had magnified God in Christ as his central position. He explains that Paul, as missionary, had a missionary focus. He explained the gospel in terms of his worldwide endeavour. He was a coherent thinker, and although not a dogmatician, his message was to proclaim the gospel of Christ in fullness. His missionary message had implications for the churches to which he conveyed his wonderful essential gospel. Paul's theology has the wonderful implication that life and death are in God's hand and that God creates the future with glory for those in Christ.

\subsection{Paul's own death}

Green (2002:48) is of the opinion that Paul affirms a profound continuity between life in this world and life everlasting with God. He says that the present humanity is frail, deteriorating and weak, but to share eternal life the bodies must be transformed. He proclaims the promise of transformation of the bodies into glorified bodies to his audience (2002:48). He is, therefore, of the opinion that, for Paul, death is near. However, the transition from the tent-like house to the house from God means that he will not be naked but clothed. The explanation of life after death is regarded in the realization that he may die before the parousia, something Paul earlier did not expect.

Danker (1968:553) states that Paul wishes to explain the hope for life after death as a new life with God. Although death is at work in Paul, the life of Jesus became apparent in his mortal body, therefore, consolation is present. The contrast is between the benefit that is the result from death and the sufferer's present situation. Paul experiences the groaning as being in proportion to the desire for the future blessing and that the body will be equipped for the future blessing. The body will be equipped for celestial existence (Danker 1968:554), therefore, it does not place him at a disadvantage (1968:555). Paul wants to explain that if he dies before the parousia, his authority as apostle will not be diminished. He seeks consolation in the fact that, though he may die, the future is ascertained in God (1968:556).

Collins (2013:105) also regards Paul's view on his own death as part of his discussion of the theme. He may still believe that he will be alive at the parousia, but also refers to his imminent death and the death of his readers in general. Therefore, he uses the metaphor of the tent.

Bultmann (1985:133) asks whether the tent's breaking down refers to Paul's own death or the parousia and he explains that death is clearly not regarded as 
annihilation, but rather as wonderful new life, because a new garment/building is prepared. Paul expects the parousia soon and regards it as normal that one will see it (Bultmann 1985:138).

Matera (2003:118) is of the opinion that Paul shifted his thinking on the resurrection of the body from 1 Corinthians 15 because of the new situation of his own imminent death. Death has been conquered and Paul is of the opinion that he will be clothed by the heavenly body (Hughes 1962:171). Matera (2003:122) sees nakedness as referring to his death, but he will not be found naked because at death he will be clothed from heaven by the new body.

It is clear that Paul has the unconditional belief that he will experience full life with Christ after death (see Dunn 1998:487ff). He is clearly of the opinion that he will die soon, but that death will not be a disaster as he will receive a building in heaven-full life with God. He will experience total bliss because God gives life even after death.

\subsection{Intermediate state}

Pop (1971:152 ff.) refers to the intermediate state between death and the resurrection and he asks whether biblical material anticipates a waiting between death and the resurrection of the dead person, or whether the biblical material anticipates immediate resurrection (1971:152 ff). In the Old Testament, Sheol is originally explained as the abode after death, but in later eschatology resurrection of the body is expected. In the New Testament passages, such as the reference to the rich man and Lazarus, the words of exchange between Jesus and the murderer on the cross, and when Luke explains that the resurrection has not yet taken place since the rich man's brothers are still alive on earth, and Jesus' account, refer to the rich man in heaven who has not yet experienced the resurrection (Pop 1971:142 ff.). According to Pop, Paul also refers in 2 Corinthians 5:1-10 to an intermediate state because we know that even though the earthly tent is dismantled, but we have the house of God until the resurrection (Pop 1971:141ff.). He is of the opinion that Paul's perspective is from an eschatology grounded in a Greek dualism, because the soul will flee the problems of the body (1971:147).

Hanhart (1969:446) refers to the fact that Culmann envisaged an intermediate state between the coming of Christ and the death of the person, and that the final resurrection will only take place at a later stage. He is, however, critical towards Culmann's views and is of the opinion that this viewof the intermediate state cannot be substantiate. Zorn (1989:97) accepts that many scholars say that there must be some kind of intermediate state between death and the resurrection. The question is whether Paul expects an intermediate state after death because of his views in 2 Corinthians 5 and 1 Corinthians 15. Does he 
have conflicting views? Zorn (1989:97) is of the opinion that Paul obviously is contrasting the house made with hands eternal in heaven with the present earthly tent-house. He is of the opinion that Paul is seriously considering the possibility that his death may take place before Christ's return. The interpretation is, thus, in favour of individual eschatology. A building not made with hands can only properly be a reference to the corporate solidarity with the church in Christ, but the building of God stresses the heavenly glory and permanence of the individual resurrected body as contrast with the present transition mortal bodies: "The fact that Paul is hoping for resurrection transformation during his lifetime so that it will not be necessary for him to experience the unclothed state of death and of being a naked spirit is confirmed by Paul's use of the verb 'to be clothed upon' (ependusaslhai) both in VSS. 2 and 4 (Zorn 1989:99). If the believer dies before the Lord returns he leaves his earthly tent-house, which is buried and remains in the grave until the parousia and emigrates to be with his Lord in the meantime, for to be absent from the body is to depart out of the body to be present and dwell in the presence of, or to be at home with the Lord" (Zorn 1989:102). In 2 Corinthians 5:1-10 Paul expects that he will immediately experience life with God; in 1 Corinthians 15 he expects resurrection of the body.

Cranford (1976:95) refers to the real question of the intermediate state and he refers to the metaphorical nature of Paul's expression. He mentions three obstacles, namely the belief that 1 Corinthians 15 is clearly parallel to 2 Corinthians 5 ; secondly, that in 2 Corinthians 5 the Apostle speculates on the metaphysical details of the afterlife; and thirdly, the thought of Paul does not lend itself to a systematically neat theological package. He, however, explains that the moment death is derived from the 'in Christ' concept, the metaphors and judgements are seen as stressed. He writes: "Did Paul believe in an intermediate state? This interpretation answers affirmatively. But Paul was not concerned about metaphysical details. For him, death means the deepening of our union with Christ as we possess the heavenly home (w. 1-2), put on this heavenly life (v. 2-4), and make our home in the true homeland with Christ (v. 8). This existence whatever its nature-body or spirit-is conscious union with Christ. That is the 'gain' of death (Phil. 1:21)." (Cranford 1976:100).

Osei-Bonsu (1986:81-82) asks whether 2 Corinthians 5 teaches the reception of the resurrected body at the moment of death. He differs from those who see Paul as receiving a spiritual new body at the moment of death by referring to firstly, the destruction of the earthly house or tent, which refers possibly to Paul's pre-parousia death, and secondly, that the building from God at death means the individual resurrected body, not the church as the body of Christ. He understands 2 Corinthians 
5:6-9 as an intermediate state where the soul is disembodied from the body and it is an intermediate state between death and the resurrection.

Hanhart (1969:445-446) is of the opinion that Paul was a revered agnostic concerning the nature of life to come, but that he, nevertheless, fostered a radiant hope of life eternal with Christ. He is of the opinion that it is very clear that the death in Christ is the death with Christ and that when you die you are with Christ and you receive the fullness of life with Christ. He refers to the fact that Paul's age and experience of being in mortal danger could have influenced his view of death: "Paul's Pauline eschatology appears to have two poles. His hope is expressed both in terms of the parousia, or the resurrection of the dead, and in terms of the entrance into an eternal home upon death in order to live with Christ".

Dunn (1998:490) is of the opinion that all we need to note is that Paul envisaged an intermediate state. Beyond death and the parousia the process of salvation is still incomplete, which can only be resolved by the new body of the resurrection.

It must be accepted that Paul, indeed, had the idea of an intermediate state. He accepted that God will rule over his life and death. Even if he dies, he will be with God, although the resurrection has not yet taken place. He will receive a place in heaven, full of glory. This is made clear from his reference to the building and clothes in 2 Corinthians 5 but according to 1 Corinthians 15 the resurrection of the body will take place at the parousia. The way in which the metaphors are structured in 2 Corinthians 5 allows for an expectation of life with Christ immediately after death while waiting for the resurrection of the body. The implications are that the resurrection is still to come. The resurrection will be the final consummation of the glory that the believer had already received at death. He does not fear the intermediate state, but longs for the building in heaven. The future will also mean that he will experience the resurrection. There is, therefore, no uncertainty in his mind. The future is secured in Christ.

\subsection{Challenge to the belief in heaven: symbolic future life?}

Mackay (1991:162-165) explains that that the metaphors may be largely ornamental and that the reference to the tent and the abode in heaven is only superficial, or that it can be interpreted literally: "The essential difference in practice between these two approaches is this: ornamental metaphors just need to be translated into literal speech, in order to make clear the information intended; exploratory metaphors, on the other hand, like all literary works, need to be explored imaginatively, their hints, allusions and implications followed as far as they lead us. In order to practice that exploring we must do the following: (1) guess what the subject is that the particular symbol can most appropriately be taken to be a window onto; (2) discover as much as we can about the reality used 
as a symbol, that is, what it was that the author was concretely imagining when using it; (3) look at the (mysterious) subject through the window of the (betterknown) symbol, thereby taking in the glimpses, following the trails pointed out, making guesses." According to him, Paul refers to symbols as his earthly tenthouse, as the wilderness tabernacle is destroyed, but the end of all earthly things at the parousia is a building from God, a house not made with hands, the symbol he devotes to glorious heavenly temple. His conclusion is, thus, that Paul's corporate language can be taken as intentional and his symbolism can be taken as revealing, and not simply as ornamental.

\subsection{Universalistic eschatology?}

Collins (2013:112-113) emphasises that Paul refers to well-known Hellenistic views, but that he also wishes to emphasise the full glory of the eschatological life with Christ. His own frailty is changed by die wonder of Christ's renewal. Bultmann (1985:145) is of the opinion that Paul's zeal to serve God is free from anxiety, because it does not fear death, but has a tacit longing for death. On judgement day the person will receive the full benefit of the heavenly house (Omanson \& Ellington 1993:95). Although the glory after death is certain, it is not for all. Although Paul accepts the intrinsic value of the universalistic eschatology, he clearly sees the life in heaven as the life for the believer who receives the glory from God. It is for those with God. They will receive the fullness of glory.

\section{Missiological implications}

What are the missiological implications of Paul's view that the tent will be taken down and that future life of glory is possible?

First of all it gives the sense of the importance of mission. This life will pass. A future life with God is possible. This must be proclaimed in the present world. This does not mean that the present life is totally unimportant. Paul's reference to the life of the church in the present world explains that fully. But, life with God after the tent has been demolished will be full of glory. Therefore Bosch (1991:414) also writes: "Evangelism offers people salvation as a present gift and with it assurance of eternal bliss. People are, even without realizing it, desperately searching for a meaning to life and history; this impels them to look for a sign of hope amid the widespread fear of global catastrophe and meaninglessness." (it. Bosch).

Secondly the full glory of the resurrection means that the beauty of the gospel must be proclaimed. There can be no doubt that Paul regards the building and clothes of the future as beautiful because God supplies it. The gospel is full of the wonder of God. Mission is about the beautiful message of life with God. 
Thirdly the gospel entails new life. Mission has to do with new life. Life is not dreadful for the believer because God makes life with Him possible. In this regard Bevans and Schroeder (2006:345) write: "Full humanity is achieved not only through economic security or political autonomy, but also and most fundamentally through the communion with God in Christ and transformation by the gospel. This is because, as Catholics, Evangelicals and Pentecostals acknowledge, human beings are sinners and so are in need of a restoration of right relation with God as well as with other human beings of all of creation."

Fourthly there is hope possible in the new life. Because of God's intervention life can be good awaiting the glory after this life. Skreslet (2012:70-72) explains how salvation has to integrate horizontal and vertical elements. Salvation can therefore include aspects such as deliverance from danger, redemption from judgement and peace between enemies.

Fifthly the image of God can be restored in humans in the resurrection. Life after death has the implication that the full image of God in creation is restored. Schreiner (2001:466) writes: "An investigation of 2 Corinthians 5:1-10 reveals no departure from standard Pauline teaching on the resurrection. Our present body is compared to an earthly house that is slowly becoming dilapidated and will eventually be torn down. Our future body, on the other hand, is heavenly and eternal, for it is from God himself".

Sixthly mission is proclaiming radically that even the suffering of this life has not the last word. God's comprehensive redemption includes new possibilities on political, economic, social and spiritual life (Wright CJH 2008:268-269) but also that suffering will be overcome in the full redemption in Christ.

Finally Harris (2005:402-403) is of the opinion that Paul, in 2 Corinthians 5:18 , although he did not despise mortal embodiment, eagerly awaited the future life with Christ and the end of the imperfections of earthly life.

\section{Conclusion}

Paul realizes that he will not live till the parousia. He believes that he will immediately be with Christ. He will experience full glory. Heaven is for real. Heaven is not a myth. Paul emphasises the fact that Christian eschatology is radically linked to the belief in heaven and that aspect should be proclaimed in the church of Christ.

This is essential for mission. The present day emphasis on this life alone does not take into account the glory of Paul's expectation. In mission, it is necessary to proclaim the fullness of the gospel of Christ's expectation of life after death and that the building from God is awaiting the believer. It should be recognised that Paul's explanation is essential for the hope and the comfort of the Christian. In mission, it is possible to spread the comfort of life after death to all. In 2 Corinthians 5:11- 
21, Paul pleads that all will accept this gospel and be reconciled with God. Being reconciled with God they will also long to receive the building in heaven.

\section{Bibliography}

Barnett, P. 1988. The message of 2 Corinthians. Downers Grove, IL: IVP. [The Bible Speaks Today].

Barret, C.K. 1976. The second epistle to the Corinthians. London: Black. [Black's New Testament Commentaries].

Bevans, S.B. \& Schroeder, R.P. 2006. Constants in context: a theology of mission for today. Maryknoll, NY: Orbis.

Bosch, D.J. 1991. Transforming mission: paradigm shifts in theology of mission. Maryknoll, NY: Orbis Books.

Bultmann, R. 1976/1985. The second letter to the Corinthians. [Translated by R.A. Harrisville]. Minneapolis, MN: Augsburg.

Collins, R.F. 2013. Second Corinthians. Grand Rapids, MI: Baker Academic. [Paideia Commentaries on the New Testament].

Cranford, L.L. 1976. New look at 2 Corinthians 5:1-10. Southwestern Journal of Theology. 19(1):95-100 [ATLA Religion Database with ATLASerials, EBSCOhost, viewed 12 September 2014].

Danker, F.W. 1968. Consolation in 2 Cor. 5:1-10. Concordia Theological Monthly. 39(8):552-556. [ATLA Religion Database with ATLASerials, EBSCOhost, viewed 12 September 2014].

Dunn, J.D.G. 1998. The theology of Paul the Apostle. Edinburgh: T\&T Clark.

Green, J.B. 2002. Eschatology and the nature of humans: a reconsideration of pertinent evidence. Science and Christian Belief. 14(1):33-50 [ATLA Religion Database with ATLASerials, EBSCOhost, viewed 12 September 2014].

Hanhart, K. 1969. Paul's hope in the face of death. Journal of Biblical Literature. 88(4):445-457. [ATLA Religion Database with ATLASerials, EBSCOhost, viewed 12 September 2014].

Harris, M.J. 1971. 2 Corinthians 5:1-10: watershed in Paul's eschatology? Tyndale Bulletin. 22:32-57. [ATLA Religion Database with ATLASerials, EBSCOhost, viewed 12 September 2014].

Harris, M.J. 2005. The second epistle to the Corinthians. Grand Rapids, MI: Eerdmans. [The New International Greek Testament Commentary].

Hughes, P.E. 1962. Paul's second epistle to the Corinthians. Edinburgh: Marshall, Morgan \& Scott. [The New London Commentary on the New Testament].

Macky, P.W. 1991. St Paul's collage of metaphors in 2 Corinthians 5:1-10: ornamental or exploratory. Proceedings (Grand Rapids, Mich.) 11:162-173. [ATLA Religion Database with ATLASerials, EBSCOhost, viewed 12 September 2014].

Matera, FJ. 2003. II Corinthians: a commentary. Louisville, KY: Westminster John Knox Press. [The New Testament Library].

Omanson, R.L. and Ellington, J. 1993. A handbook on Paul's second letter to the Corinthians. New York: UBS. 
Osei-Bonsu, J. 1986. Does 2 Cor 5:1-10 teach the reception of the resurrection body at the moment of death? Journal for the Study of the New Testament. 28:81-101. [ATLA Religion Database with ATLASerials, EBSCOhost, viewed 12 September 2014].

Philo Judaeus De virtutibus (ed. L. Cohn) Philonis Alexandrini opera quae supersunt, vol. 5. Berlin: Reimer, 1906 (repr. De Gruyter, 1962), http://khazarzar.skeptik.net/books/ philo/virtutig.pdf Visited 8 September 2015.

Pop, F.J. 1971. De tweede brief van Paulus aan de Corinthiers. Nijkerk: Callenbach. [De Prediking van het Nieuwe Testament].

Schnelle,U. 2005. Apostle Paul: His life and theology. (Translated by ME Boring) Grand Rapids, MI: Baker Academic..

Schreiner, T.R. 2001. Paul: Apostle of God's glory in Christ: A Pauline theology. Downers Grove, IL: IVP.

Skreslet, S.H. 2012. Comprehending mission: The questions, methods, themes, problems and prospects of missiology. Maryknoll, NY: Orbis Books.

Thiselton, A.C. 2012. Life after death: a new approach to the last things. Grand Rapids, MI: Eerdmans.

Van der Watt, J.G. 2000. Family of the King: Dynamics of metaphor in the Gospel according to John. Leiden: Brill.

Wolff, C. 1989. Der zweite Brief des Paulus an die Korinther. Berlin: EVB. [Theologischer Handkommentar zum Neuen Testament 8].

Wright, C.J.H. 2008. The mission of God: unlocking the Bible's grant narrative. Nottingham: InterVarsity.

Wright, N.T. 2005. Paul in fresh perspective. Minneapolis: Fortress.

Wright, N.T. 2008. Surprised by hope: Rethinking heaven, the resurrection, and the mission of the church. New York: Harper one.

Zorn, R.0. 1989. II Corinthians 5:1-10: individual eschatology or corporate solidarity, which? Reformed Theological Review. 48(3):93-104. [ATLA Religion Database with ATLASerials, EBSCOhost, viewed 12 September 2014]. 